\title{
Tingkat $\mathrm{HbA1c}$ dengan tingkat kreatinin pada pasien dengan Diabetes Mellitus tipe 2
}

Putri Nur Cahyani ${ }^{a, 1^{*}}$, Atik Martsiningsih a, ${ }^{\text {, }}$, Budi Setiawan ${ }^{\text {a,b, } 3}$

a Jurusan Analis Kesehatan, Poltekkes Kemenkes Yogyakarta, Jl Ngadinegaran MJIII No 62 Yogyakarta 55141

b PUI Novakesmas, Jl Tata Bumi No 3 Sleman 55293

${ }^{1}$ pcahyani26@gmail.com*; atikskripsikti20@gmail.com; budi.setiawan@poltekkesjogja.ac.id

*korespondensi penulis

\begin{tabular}{ll}
\hline \multicolumn{2}{l}{ Informasi artikel } \\
\hline Sejarah artikel: & \\
Diterima & $: 5$ Maret 202I \\
Revisi & $: 7$ Maret 202I \\
Dipublikasikan & $: 8$ Maret 202I \\
\hline
\end{tabular}

\section{Kata kunci:}

Diabetes Mellitus Tipe 2

Glukosa darah

$\mathrm{HbA1c}$

Kreatinin

\section{Key word:}

Type 2 Diabetes Mellitus

Blood glucose

$\mathrm{HbA1c}$

Creatinine

\begin{abstract}
ABSTRAK
Latar Belakang: Prevalensi Penderita Diabetes Mellitus Tipe 2 di Indonesia terus meningkat. Pengertian komplikasi akibat penyakit ini, salah satunya adalah nefropati diabetik atau kerusakan nefron ginjal. Tujuan: Untuk mengetahui hubungan antara kadar $\mathrm{HbA1c}$ dengan kadar kreatinin pada penderita Diabetes Mellitus Tipe 2. Metode: Penelitian ini merupakan eksperimen observasional dengan pendekatan cross sectional berdasarkan data sekunder. Penelitian dilaksanakan pada bulan Februari sampai April 2020. Populasi penelitian ini adalah anggota Prolanis (Program Lanjutan Penanggulangan Penyakit Kronis) di Gamping 1 Puskesmas Sleman Yogyakarta. Sampel dengan 24 pasien. Analisis data menggunakan uji Spearman. Hasil: Dari hasil uji normalitas dengan menggunakan Shapiro Wilk test diperoleh data tidak berdistribusi normal sehingga dilanjutkan dengan uji rank spearman diperoleh $r$ sebesar -0,006 dan nilai $p$ dengan sig. (2-tailed) 0,961 atau> 0,05 (H0 diterima). Artinya tidak ada hubungan antara kadar $\mathrm{HbA1c}$ dengan kadar kreatinin darah pada penderita DM tipe 2. Kesimpulan: Tidak ada hubungan antara kadar HbA1c dengan kadar kreatinin pada penderita Diabetes Mellitus Tipe 2
\end{abstract}

\section{ABSTRACT}

The relationship of HbA1c levels with creatinin levels in Diabetes Mellitus Type 2 patients. Background: People with Type 2 Diabetes Mellitus in Indonesia continue to increase in prevalence. Understanding of complications due to this disease, one of which is diabetic nephropathy or damage to kidney nephrons. Objective: To determine the relationship between HbA1c levels and creatinine levels in patients with Type 2 Diabetes Mellitus. Method: This study was an observational experiment using a cross sectional approach based on secondary data. The research was carried out in February to April 2020. The population of this research study is a member of Prolanis (Chronic Disease Management Advanced Program) in Gamping 1 Puskesmas Sleman Yogyakarta. Sample with 24 patients. Analysis of data using the Spearman's test. Results: From the results of the normality test using the Shapiro Wilk test data obtained were not normally distributed so that continued with the Spearman rank test obtained $r$ of -0.006 and $p$ values with sig. (2-tailed) of 0.961 or $>0.05$ ( $\mathrm{H} 0$ received). This means that there is no relationship between $H b A 1 c$ levels and blood creatinine levels in patients with type 2 DM. Conclusion: There is no relationship between HbA1c levels and creatinine levels in patients with Type 2 Diabetes Mellitus. 


\section{Pendahuluan}

Prevalensi dari penyakit Diabetes Mellitus (DM) semakin meningkat terutama di negara yang sedang berkembang (Arisman, 2008). Pada tahum 2024 penderita diabetes diprediksi mencapai 692 juta jiwa. Angka ini berdasarkan catatan International Diabetes Federation (IDF) pada 2015 yang menyebut jumlah penderita diabetes mencapai 415 juta jiwa, kemudian pada tahun 2017 mencapai 425 juta. Di Indonesia berdasarkan Riset Kesehatan Dasar (Riskesdas) dari tahun 2013 hingga 2018 prevalensi Diabetes Melitus (DM) meningkat dari $6.9 \%$ menjadi $8.5 \%$, yang artinya terdapat 22.9 juta penduduk menderita DM. Penyakit Diabetes Melitus merupakan salah satu penyakit degeneratif yang tidak dapat disembuhkan, namun kadar glukosa dalam darah dapat dikendalikan agar tetap pada ambang batas normal.

Diabetes Melitus Tipe 2 merupakan diabetes yang prevalensinya tinggi. Diabetes tipe 2 ini dapat terjadi karena gaya hidup yang tidak sehat, selain dari faktor keturunan, DM tipe 2 berkembang sangat lambat dan tidak mutlak memerlukan suntikan insulin karena pankreasnya masih menghasilkan insulin. Tipe DM ini dapat menyebabkan berbagai komplikasi diantaranya komplikasi pada syaraf, koma hiperglikemi, koma hipoglikemi, komplikasi pada mata, luka yang sulit sembuh, dan komplikasi pada ginjal.

Penderita diabetes mellitus mempunyai kecenderungan menderita nefropati 17 kali lebih sering dibandingkan dengan orang non-diabetik. Kerusakan pada ginjal tersebut dapat didiagnosa dengan pemeriksaan tes fungsi ginjal, salah satunya adalah pemeriksaan kadar kreatinin dalam darah. Pemeriksaan kadar kreatinin dalam darah merupakan salah satu parameter yang digunakan untuk menilai fungsi ginjal, karena konsentrasi dalam plasma dan ekskresinya di urin dalam 24 jam relatif konstan. Pemeriksaan kreatinin ini, sangat membantu kebijakan melakukan terapi pada penderita gangguan fungsi ginjal. Kadar normal dari kreatinin adalah $<1,20 \mathrm{mg} / \mathrm{dL}$.

Masyarakat seringkali mengabaikan penyakit DM dan tidak mengontrol gula darahnya sehingga terkadang pasien menyadari bahwa dia menderita penyakit DM setelah timbulnya komplikasi. Skrining kadar kreatinin darah perlu dilakukan untuk mendeteksi adanya kerusakan ginjal pada penderita DM Tipe 2, karena penderita DM merupakan salah satu orang yang berisiko untuk mengalami kerusakan ginjal akibat dari kadar glukosa dalam darah yang terlalu tinggi dan terjadi secara terus menerus. Untuk mengontrol gula darah dan ketaatan diet dan konsumsi obat maka setiap 3 - 6 bulan dilakukan pemeriksaan HbA1c. Berdasarkan uraian diatas peneliti tertarik untuk mengetahui adakah hubungan antara kadar $\mathrm{HbA1c}$ dengan kadar kreatinin pada penderita Diabetes Melitus Tipe 2.

\section{Metode}

Jenis penelitian ini merupakan penelitian Observasional analitik. Sampel dalam penelitian ini adalah pasien Diabetes Melitus Tipe 2 di Puskesmas Gamping 1 Sleman Yogyakarta yang berjumlah 24 sampel, jumlah ini berdasarkan data pasien yang melakukan 
control secara rutin di puskemas tersebut dengan memanfaatkan data sekunder. Data kadar glukosa dan kadar kreatinin darah pasien DM tipe 2 diperoleh dari hasil pemeriksaan darah di Laboratorium Klinik Swasta Cito Yogyakarta yang sudah direkap oleh pihak Puskesmas Gamping 1 Sleman. Analisis uji menggunakan aplikasi pengolah data menggunakan uji uji Saphiro - wilk test dan dilanjutkan dengan uji spearman.

Penelitian yang dilakukan ini sudah mendapatkan surat layak etik dari Komisi Etik Penelitian Kesehatan Poltekkes Kemenkes Yogyakarta dengan nomor eKEPK/POLKESYO/0141/II/2020. Penelitian dilaksanakan pada bulan Februari hingga April 2020 di Puskesmas Gamping 1 Sleman Yogyakarta.

\section{Hasil dan Pembahasan}

Penelitian ini dilaksanakan pada bulan Februari sampai dengan bulan April 2020. Pada penelitian ini di dapatkan subyek penelitian sebanyak 24 orang yang dilihat dari rekam medis dan data program lanjut usia (prolanis) yang tersedia di Puskesmas Gamping 1 Sleman Yogyakarta yang terdiri dari 9 orang subyek laki-laki dan 15 orang subyek perempuan. Pemilihan subyek penelitian dilakukan dengan melihat kriteria inklusi dan eksklusi yang sudah di tetapkan oleh peneliti pada penelitian ini. Pada penelitian yang dilakukan seharusnya sampel yang digunakan adalah 28 sampel namun karena hanya ada 24 sampel yang memenuhi kriteria maka hanya 24 sampel yang digunakan. Penyebab dari 4 sampel tidak digunakan adalah 4 sampel tersebut tidak rutin melakukan medical check up 3 periode, hanya mengikuti 2 periode sehingga tidak dapat dilakukan uji statistik.

\section{Karakteristik Dasar Subjek Penelitian}

Penelitian ini melibatkan subyek penelitian sebanyak 24 orang pasien yang memiliki data yang sesuai dengan penelitian ini. Subyek penelitian ini dinyatakan masuk dalam kriteria inklusi dan eksklusi. Berdasarkan penelitian yang dilakukan diperoleh karakteristik dasar subjek penelitian sebagai berikut :

Tabel 1. Karakteristik Subyek Penelitian

\begin{tabular}{lll}
\hline Variabel & Jumlah & Presentase (\%) \\
\hline Jenis Kelamin & & \\
Laki - laki & 9 & 37,5 \\
Perempuan & 15 & 62,5 \\
Usia & & \\
$40-50$ & 3 & 12,50 \\
$51-60$ & 12 & 50 \\
$61-70$ & 9 & 37,50 \\
Lama Menderita (Tahun) & & \\
$1-5$ & 19 & 79,16 \\
$6-10$ & 2 & 8,33 \\
$11-15$ & 3 & 12,50 \\
\hline
\end{tabular}

Pada tabel 1 menunjukan bahwa 62,5\% penderita Diabetes Melitus Tipe 2 adalah berjenis kelamin perempuan. Sedangkan untuk penderita dengan jenis kelamin laki - laki hanya $37,5 \%$. Sehingga proporsi jenis kelamin ini tidak seimbang, dengan perbandingan 1:3 untuk laki - laki dan perempuan. Persebaran usia penderita DM Tipe 2. Usia penderita adalah antara 40 sampai 70 tahun. Dengan sebaran 12,50\% di rentang usia 40 - 50 tahun, $50 \%$ dengan usia 51 - 60 tahun, dan 37,50 \% di rentang usia 61 - 70 tahun. Lamanya pasien menderita DM Tipe 2 ini berkisar dari 1 sampai 15 tahun lamanya. Sebaran datanya 1 - 5 tahun sebanyak 79,16\%, 
6 - 10 tahun sebanyak 8,33\% dan 12,50\% pada 11 - 15 tahun. Sehingga diketahui bahwa sebagian besar pasien berada pada rentang 1 - 5 tahun.

Hasil dari penelitian yang dilakukan didapatkan data dengan berbagai karakteristik subyek penelitian. Berdasarkan hasil karakteristik subyek berdasarkan jenis kelamin dari 24 pasien didapatkan 9 orang untuk pasien pria (37,50\%) dan 15 orang pasien wanita $(62,50 \%)$. Dengan data tersebut membuktikan bahwa jumlah pasien DM tipe 2 dengan kelamin wanita lebih banyak dibandingkan dengan pasien DM tipe 2 yang berjenis kelamin laki-laki. Penelitian yang dilakukan oleh Sri Septi Maulina (2016) juga menunjukan hasil yang sama, penderita DM terbanyak adalah yang berjenis kelamin perempuan. Wanita lebih berpotensi menderita DM dikarenakan pengaruh dari hormon-hormon yang disekresi dari ovarium, yaitu progesteron dan estrogen. Hormon-hormon ini dapat meningkatkan insulin atau dapat memperkuat rangsangan glukosa terhadap sekresi insulin. Efek perangsangan dari hormonhormon progesteron dan estrogen inilah yang merupakan efek pemanjangan dari salah satu jenis hormon yang dalam jumlah besar dapat menyebabkan sel-sel pulau langerhans menjadi kelelahan dan akibatnya timbul DM (Guyton and hall, 2007).

Karakteristik dasar subyek penelitian untuk kategori usia didapatkan data bahwa usia penderita DM Tipe 2 di wilayah Puskesmas Gamping 1 adalah berkisar antara 40 sampai 70 tahun. Peningkatan kadar HbA1c dapat dipengaruhi oleh beberapa faktor diantaranya seiring bertambahnya usia maka metabolisme tubuh akan menurun, aktivitas fisik yang berkurang, obesitas atau kegemukan, stres, adanya penyakit lain karena faktor usia, dan karena resistensi insulin akibar berkurangnya masa otot dan perubahan vaskular. Prevalensi terjadinya Diabetes Melitus meningkat seiring dengan pertambahan usia (Rochmah, 2009). Banyak kasus DM Tipe 2 yang terjadi pada usia dewasa sehingga memungkinkan seseorang untuk mendapatkan komplikasi DM bila pemantauan kadar glukosanya tidak diperhatikan (Soewondo, 2004).

Berdasarkan Tabel 1 lamanya pasien menderita DM Tipe 2 ini berkisar dari 1 sampai 15 tahun lamanya. Sebaran datanya 1 - 5 tahun sebanyak 79,16\%, 6 - 10 tahun sebanyak 8,33\% dan $12,50 \%$ pada 11 - 15 tahun. Sehingga diketahui bahwa sebagian besar pasien berada pada rentang 1 - 5 tahun. Semakin lama seseorang menderita DM Tipe 2 apabila tidak rajin mengontrol penyakit tersebut maka dapat menimbulkan komkplikasi diabetik.

Tabel 2. Karakteristik Subyek Penelitian Berdasarkan Kriteria Pengendalian HbA1c dan Kadar Kreatinin Darah

\begin{tabular}{llll}
\hline & \multicolumn{3}{l}{ Jumlah [Presentase $(\%)]$} \\
\cline { 2 - 4 } & $\begin{array}{l}\text { Periode 1 (Maret } \\
\text { 2019) }\end{array}$ & $\begin{array}{l}\text { Periode 2 } \\
(\text { Oktober 2019) }\end{array}$ & $\begin{array}{l}\text { Periode 3 } \\
\text { (April 2020) }\end{array}$ \\
\hline $\begin{array}{l}\text { Kriteria } \\
\text { Pengendalian }\end{array}$ & & \\
HbA1c (\%) & & & \\
\hline Baik $(<5,7)$ & 0 & $2(8,33)$ & $1(4,16)$ \\
Sedang $(5,7-6,4)$ & $4(16,66)$ & $22(91,66)$ & $23(95,83)$ \\
Buruk $(<=6,4)$ & $20(83,33)$ & & \\
\hline $\begin{array}{l}\text { Kreatinin } \\
\text { (mg/dL) }\end{array}$ & & $20(83,33)$ & $19(79,16)$ \\
\hline Normal & $21(87,50)$ & $4(16,66)$ & $5(20,83)$ \\
\hline Tidak Normal & $3(12,50)$ & & \\
\hline
\end{tabular}


Pada tabel 2 diketahui sebaran data kadar HbA1c pada subjek penelitian, diketahui bahwa tidak ada subjek dengan kriteria kadar HbA1c baik. Diketahui bahwa 4,16\% dengan kriteria sedang dan 95,83\% dengan kriteria buruk. Kriteria tersebut mengacu pada keteraturan diet makanan dan kepatuhan dalam mengkonsumsi obat pada 3 bulan terakhir. Kriteria baik berarti bahwa dalam 3 bulan terakhir kontrol glukosa dilakukan dengan baik diantaranya dengan mengkonsumsi obat secara rutin dan menjaga pola makan agar kadar glukosa darah dapat terkendali dengan baik. Begitu juga dengan kriteria sedang dan buruk, kontrol tersebut dilakukan dengan sedang dan dengan buruk. Kadar kreatinin darah ini menunjukan adanya kerusakan pada ginjal. Namun, data yang didapatkan hanya ada 20,83\% subyek dengan kadar kreatinin tidamk normal atau diatas nilai rujukan dan 79,16\% subyek dengan kadar kreatinin normal.

$\mathrm{HbA1c}$ adalah zat yang terbentuk dari reaksi kimia antara glukosa dan hemoglobin (bagian dari sel darah merah). Pemeriksaan HbA1c digunakan sebagai indikator dalam memantau kontrol gula darah jangka panjang, diagnosis, penentuan prognosis, pengelolaan penderita DM. Dengan mengukur glycohemoglobin dapat diketahui berapa besar persentasi hemoglobin yang mengandung gula. Bila kadar gula darah tinggi dalam beberapa minggu, maka kadar HbA1c juga akan tinggi. Ikatan HbA1c yang terbentuk bersifat stabil yang dapat bertahan hingga 2-3 bulan. Kadar HbA1c akan mencerminkan rata-rata kadar dalam jangka waktu 2-3 bulan sebelum pemeriksaan. Dengan mengukur kadar $\mathrm{HbA1c}$ dapat diketahui kualitas kontrol penyakit DM dalam jangka panjang, sehingga diketahui ketaatan penderita dalam menjalani perencanaan makan dan pengobatan.

Pemeriksaan kadar HbA1c yang dilakukan dalam 3 periode didapatkan hasil pada periode 1 yaitu $0 \%$ dengan kadar $\mathrm{HbA1c}$ baik, 16,66 \% dengan kadar $\mathrm{HbA1c}$ sedang dan 83,33 \% dengan kadar glukosa buruk. Periode 2 menunjukkan hasil kadar HbA1c 0 \% baik, $8,33 \%$ sedang, dan 91,66 \%. Kemudian pada pemeriksaan periode ketiga didapatkan hasil kadar HbA1c 0 \% baik, 4,16 \% sedang, dan 95,83 \% buruk. Dengan data ini dapat diketahui bahwa setiap periode terjadi kenaikan jumlah kadar HbA1c dengan kriteria buruk. Hal ini menunjukkan bahwa kontrol terhadap kadar glukosa darah selama 3 bulan terakhir tidak dilakukan dengan baik sehingga mengakibatkan hemoglobin yang terikat dengan glukosa atau glycated haemoglobin menjadi tinggi. Meskipun begitu namun kenaikan jumlah ini tidak terlalu signifikan.

Kreatinin adalah produk akhir metabolisme kreatinin. Kreatinin terutama disintesis oleh hati (Widmann, 1989). Sebagian besar kreatinin dijumpai di otot rangka, tempat zat ini terlibat dalam penyimpanan energi sebagai kreatin fodfat (CP). Jumlah kreatinin yang dihasilkan oleh seseorang setara dengan masa otot rangka yang dimilikinya (Sacher dan McPherson, 2004). Pembentukan kreatinin harian umunya tetap, dengan pengecualian pada cedera fisik berat atau penyakit degenerative yang menyebabkan kerusakan massif pada otot (Sacher dan McPherson, 2004 ). Namun jika 50\% atau lebih nefron rusak, maka kadar kreatinin meningkat (Kee, 1997). Ginjal mengekskresikan kreatinin secara sangat efisien.

The National Kidney Disease Education Program merekomendasikan penggunaan serum kreatinin untuk mengukur kemampuan filtrasi glomerolus dan digunakan untuk memantau perjalanan penyakit ginjal (Stevens LA, dkk. 2006). Diagnosis gagal ginjal dapat ditegakkan saat nilai kreatinin serum meningkat diatas rujukan normal (Kara A. 2012).

Data yang digunakan pada penelitian ini adalah data sekunder. Pemeriksaan kadar HbA1c dan kreatinin dilakukan selama 3 periode yaitu bulan Maret 2019, bulan Oktober 2019 dan bulan April 2020. Pemeriksan ini dilakukan oleh Laboratorium Swasta di Yogyakarta, 
pada periode 1 dan 2 dilakukan di Laboratorium Swata Parahita Yogyakarta dan periode 3 dilakukan di Laboratorium Swasta Cito Yogyakarta.

Hasil dari penelitian ini didapatkan hasil data selama 3 periode pemeriksaan kreatinin darah diketahui bahwa pada periode 1 kadar kreatinin normal 87,50 \% dan 12,50 \% dengan kadar kreatinin tidak normal. Pada periode 2 terdapat 83,33\% dengan kadar kreatinin normal dan 16,66 \% tidak normal, serta pada periode 3 terdapat 79,16\% kadar kreatinin darah normal dan 20,83 \% tidak normal. Dalam 3 periode menunjukkan hasil kadar kreatinin yang tidak normal meningkat setiap periode.

Mengacu pada hasil data kadar kreatinin dan $\mathrm{HbA1c}$ tersebut dapat diketahui bahwa disaat kadar HbA1c meninggi diiringi juga dengan kenaikan kadar kreatinin darah walaupun tidak signifikan.

Tabel 2 membuktikan adanya kenaikan kadar $\mathrm{HbA1c}$ dan kreatinin dari periode 1 hingga periode 3. Banyak faktor yang dapat menyebabkan hal tersebut, diantaranya adalah pasien yang tidak mematuhi diet makanan yang dianjurkan oleh dokter dan konsumsi obat yang tidak teratur. Sehingga hal ini membuat kadar glukosa dalam darah menjadi tidak terkendali sehingga menyebabkan kadar HbA1c menjadi naik. Sebagian kadar kreatinin juga mengalami kenaikan hal ini kemungkinan didapatkan dengan waktu lamanya menderita DM Tipe 2 dengan kadar HbA1c yang tidak terkendali sehingga mulai terjadi kerusakan nefron pada ginjal. Hal ini menunjukkan adanya risiko kenaikan kadar kreatinin darah pada penderita DM Tipe 2.

Tabel 3. Hasil Uji Normalitas Data dengan Analisis SPSS

Uji Normalitas Data

\begin{tabular}{|c|c|c|c|c|c|c|}
\hline & \multicolumn{3}{|c|}{ Kolmogorov-Smirnova } & \multicolumn{3}{|c|}{ Shapiro-Wilk } \\
\hline & Statistic & $\mathrm{df}$ & Sig. & Statistic & $\mathrm{df}$ & Sig. \\
\hline Kadar $\mathrm{HbA1c}$ & .085 & 72 & $.200^{*}$ & .983 & 72 & .458 \\
\hline Kadar Kreatinin Darah & .190 & 72 & .000 & .871 & 72 & .000 \\
\hline
\end{tabular}

Uji normalitas data menggunakan uji Saphiro-Wilk diperoleh nilai kadar $\mathrm{HbA1c}$ dengan signifikansi $=0,458(>0,05)$ dan kadar kreatinin dengan signifikansi $=0,000(<0,05)$. Dengan demikian data tersebut tidak terdistribusi normal sehingga dapat dilanjutkan dengan uji spearman. 
Tabel 4. Hasil Uji Hubungan dengan Analisis SPSS

Uji Hubungan

\begin{tabular}{|c|c|c|c|c|}
\hline & & & Kadar $\mathrm{HbA1c}$ & $\begin{array}{l}\text { lar Kreatinin } \\
\text { Darah }\end{array}$ \\
\hline \multirow[t]{6}{*}{ Spearman's rho } & \multirow[t]{3}{*}{ Kadar $\mathrm{HbA1c}$} & Correlation Coefficient & 1.000 & -.006 \\
\hline & & Sig. (2-tailed) & & .961 \\
\hline & & $\mathrm{N}$ & 72 & 72 \\
\hline & \multirow[t]{3}{*}{$\begin{array}{l}\text { Kadar Kreatinin } \\
\text { Darah }\end{array}$} & Correlation Coefficient & -.006 & 1.000 \\
\hline & & Sig. (2-tailed) & .961 & \\
\hline & & $\mathrm{N}$ & 72 & 72 \\
\hline
\end{tabular}

Dari tabel Correlation menunjukan bahwa hasil uji spearman's dengan nilai r sebesar 0,006 dan nilai p dengan sig. (2-tailed) sebesar 0,961 atau >0,05 (H0 diterima). Artinya tidak ada hubungan antara kadar HbA1c dengan kadar kreatinin darah pada penderita DM tipe 2.

Menurut analisis statistik yang dilakukan data pada penelitian ini tidak normal, dilihat dari nilai kadar $\mathrm{HbA1c}$ dengan signifikansi $=0,458(>0,05)$ dan kadar kreatinin dengan signifikansi $=0,000(<0,05)$. Setelah dilakukan uji hubungan menunjukan bahwa hasil uji spearman's dengan nilai $\mathrm{r}$ sebesar -0,006 dan nilai $\mathrm{p}$ dengan sig. (2-tailed) sebesar 0,961 atau >0,05 (H0 diterima). Artinya tidak ada hubungan antara kadar $\mathrm{HbA1c}$ dengan kadar kreatinin darah pada penderita DM tipe 2.

Apabila mengacu pada analisis statistik tersebut tidak adanya hubungan antara kadar $\mathrm{HbA1c}$ dengan kadar kreatinin darah diakibatkan karena penderita DM Tipe 2 yang menjadi sampel dala penelitian ini melakukan kontrol $\mathrm{HbA1c}$ dengan baik. Hal ini dibuktikan dengan rutin melakukan pemeriksaan glukosa darah setiap bulan dan melakukan medical check up setiap 6 bulan sekali untuk diukur kadar $\mathrm{HbA1c}$, kreatinin darah, ureum darah, kolesterol total, HDL - kolesterol, LDL - kolesterol, trigliserida, mikroalbumin kuantitatif, dan pemeriksaan urin. Dengan rutin melakukan medical check up tersebut maka dapat dilakukan kontrol terhadap penderita. Penderita DM Tipe 2 tersebut juga selalu rutin mengkonsumsi obat - obatan diantaranya Metformin dan Glimepirid sehingga glukosa darah dapat dikontrol dengan baik.

Apabila dilakukan kontrol HbA1c yang baik maka kemungkinan terjadinya komplikasi ginjal atau nefropati diabetik dapat diminimalisir. Karena dengan terkontrolnya glukosa dalam darah maka kerja dari ginjal tidak menjadi berat dan dapat terjadi kerusakan pada nefron apabila hal tersebut terjadi secara terus - menerus. Dibuktikan dengan penelitian ini bahwa kegiatan prolanis untuk mengontrol kadar gula darah secara rutin dapat meminimalisir adanya kejadian nefropati diabetik.

Hasil dari penelitian ini bertolak belakang dengan penelitian yang dilakukan oleh Vithiavathi Sivasubramanian, Karthik Jetty, S. Senthil Kumar (2019). Yang menunjukkan adanya korelasi antara kadar HbA1c dengan kadar kreatinin darah pada penderita DM tipe 2. Hal ini dapat terjadi karena adanya beberapa faktor diantaranya wilayah penelitian yang berbeda yaitu di India dan di Indonesia. Subyek yang dipilih oleh peneliti juga berbeda kriterianya. Subyek yang diambil oleh peneliti adalah kelompok anggota prolanis yang sudah 
dikontrol setiap bulan. Sedangkan hasil dari penelitian ini sama dengan penelitian milik Fernando Ferino (2017). Yang menunjukkan tidak terdapat korelasi antara kadar HbA1c dengan kadar kreatinin darah.

Kelemahan dari penelitian ini adalah perlunya ditambahkan parameter lain untuk pemeriksaan tes fungsi ginjal agar benar - benar didapatkan hasil yang akurat mengenai adanya kerusakan ginjal atau komplikasi nefropati diabetik. Parameter lain tersebut diantaranya ureum, mikroalbumin urin, dan kreatinin urin untuk tes fungsi ginjal. Penelitian ini dilakukan saat adanya pandemi Covid-19 sehingga dalam pelaksanaannya kurang maksimal.

\section{Kesimpulan}

Dari penelitian ini disimpulkan bahwa tidak ada hubungan antara kadar $\mathrm{HbA1c}$ dengan kadar kreatinin darah pada penderita Diabetes Melitus Tipe 2.

Perlu dilakukan penelitian kelanjutan dengan parameter lain yaitu ureum, mikroalbumin urin, dan kreatinin urin untuk tes fungsi ginjal, sehingga diketahui adanya risiko nefropati diabetik.

\section{Daftar Pustaka}

1. Anggun, 2012. Hubungan Dislipedimia dengan Kadar Ureum dan Kreatinin Darah Pada Penderita Nefropati Diabetik. Semarang : Fakultas Kedokteran, Universitas Diponegoro.

2. Arsono, Soni. 2005. Diabetes Melitus Sebagai Faktor Resiko Kejadian Gagal Ginjal Terminal. Universitas Diponegoro. Semarang.

3. David C end Dugdale. Creatinine blood test.Available from : https:// www.nlm.nih. Gov /Medlineplus/ency/article/003475.htm.Diakses Tanggal 3 Januari 2019.

4. Dorland WA, Newman. 2010. Kamus Kedokteran Dorland edisi 31. Jakarta: Penerbit Buku Kedokteran EGC. p. 702, 1003.

5. Elizabeth J. Corwin. 2009. Buku Saku Patofisiologi Corwin. Jakarta: Aditya Media.

6. Guyton A.C. and J.E. Hall 2007. Buku Ajar Fisiologi Kedokteran. Edisi 9. Jakarta: EGC.

7. I Gusti Ayu Putu Widia Satia Padma, dkk. 2017. Gambaran Kadar Kreatinin Serum pada Penderita Diabetes Mellitus Tipe 2 di Rumah Sakit Umum Pusat Sanglah Denpasar. ISSN Online : 2549-1520, ISSN Cetak : 2338 - 1159, Vol. 5, No. 2, Desember 2017111 Hlm. 107 11.

8. Kara A. Renal function. Clinical chemistry. $6^{\text {th }}$ ed. Philadephia : Wlters Kluwer;2012.

9. Kartika, K.I\&Hasanat, N.U, .(2006). Dinamika emosi kepatuhan diet pada pasien diabetes melitus. Journal. Universitas Gajah Mada. 
10. Kee JL., 2008. Pedoman Pemeriksaan Laboratorium \& Diagnostik Cetakan I Edisi 6. Jakarta: ECG.

11. Maulina, Sri Septi. 2016. Korelasi antara Kadar Glukosa Darah dengan Kadar Kreatinin Darah pada Penderita Diabetes Melitus Tipe 2 di Rsud Dr.Moewardi Surakarta. Tugas Akhir : Universitas Setia Budi Surakarta.

12. McNaughton, Candace D. 2011. Diabetes in the Emergency Department: Acute Care of Diabetes Patients. Clinical Diabetes.

13. Notoatmodjo,S. 2010. Metodologi Penelitian Kesehatan. Jakarta : Rineka Cipta.

14. Nugraha, Gilang (2015). Panduan Pemeriksaan Laboratorium Hematologi Dasar. Jakarta: CV Trans Info Medika.

15. Perkeni, 2006, Konsensus Pengelolaan dan Pencegahan Diabetes Mellitus Tipe 2 Di Indonesia 2006, Perkumpulan Endokrinologi Indonesia, Jakarta.

16. Rinda A. 2015. Pengaruh konsentrasi asam pikrat pada penentuan kreatinin menggunakan sequential injection analysis. Jurnal Kimia. 1(2): 587 - 591.

17. Depkes, R.I., 2008. Riset kesehatan dasar (RISKESDAS) 2007. Jakarta: Badan Penelitian dan Pengembangan Kesehatan.

18. Rochmah, W.2009. Diabetes melitus pada Usia Lanjut. In:Sudoyo dkk (ed). Buku Ajar Ilmu Penyakit Dalam. Balai Penerbit FK UI. Jakarta.

19. Sacher, Ronald A dan Richard A. McPherson. 2002. Tinjauan Klinis Hasil Pemeriksaan Laboratorium. Alih bahasa : Brahm U.P dan Dewi Wulandari. Jakarta: EGC.

20. Sacher, A Ronald. 2012. Tinjauan Hasil Pemeriksaan Laboratorium. Jakarta: EGC.

21. Sari, Putri Noviana. 2019. Gambaran Kadar Kreatinin pada Serum Deproteinasi dan Non - Deproteinasi dengan Metode Jaffe Reaction. Karya Tulis Ilmiah : Politeknik Kesehatan Kemenkes Yogyakarta.

22. Soegondo, Sidartawan, Pradana Soewondo, Imam Subekti, ed. Penatalaksanaan Diabetes Melitus Terpadu. Jakarta: Balai Penerbit FKUI; 2004.

23. Soewondo P, 2009., Buku Ajar Penyakit Dalam: Insulin : Koma Hiperosmolar Hiperglikemik non Ketotik, Jilid III, Edisi 4, Jakarta: FK UI pp. 1913.

24. Sugiyono. 2013. Metode Penelitian Kuantitatif Kualitatif dan R E D. Bandung : Alfabeta.

25. Stevens LA, Coresh J, Greene T, Levey AS. Assesing kidney function-measured and estimated glomerular filtration rate. N Engl J Med. 2006;354:2473-83. 
26. Sivasubramanian, V., Jetty, K. and Kumar, S.S., 2019. Correlation of HbA1c with urinary ACR, serum creatinine and eGFR in type-2 diabetes mellitus at Puducherry, South India. International Journal of Research in Medical Sciences, 7(5), p.1924. 